\title{
9 Seeking Healing from Members of a Different Religion as a Case Against Religious Syncretism
}

In this chapter ${ }^{478}$ I argue that those cases where healing is sought from neighbours of a different religion can be regarded as evidence of superficial syncretism. At a deep level, co-operation between members of different religions is not synonymous with, nor should it be mistaken for, religious syncretism. Far from shaping some kind of shared Muslim-Christian religiosity, the practice actually serves to maintain each group's religious autonomy.

My respondents resort to healers of a different religion not because they see their religion as somehow familiar or complementary; on the contrary, they tend to view it as a source of magical powers which are as sinister as they are alien. They attribute maladies of body and mind to demons such as jinn or samovilas/samodivas (in particularly difficult cases such as possession, paralysis or terminal diseases). They consider it a matter of course that a territory inhabited by a religiously mixed human population made up of Muslims and Christians should also be visited by the supernatural beings which the two groups believe in.

As Lucy M. Garnett noted, “[t]he supernatural beings with whom the Osmanlis terrify themselves and their children have by no means the variety of those of their neighb[o]rs belonging to other mationalities, and fall, for the most part, under the denomination either of Djins or Peris" (Garnett 1909, p. 133). Evgenia Troeva-Grigorova, a Bulgarian scholar whose work focuses on this problem, writes that "the idea of the existence of Christian and Muslim jinn is easy to explain if we take into account the fact that the 'second' world is a reflection of the first" (Troeva-Grigorova 2003, p. 188, translated from Bulgarian):

Hodzha 3: What's the point of sleeping in the church? Why would you do that? [the hodzha addresses Shurfe - M.L.]

M.L.: People sometimes go there.

M.: That's superstition.

Woman Sh.: Well, what is there to be done when you catch something [nasty] from a giaour dzhin? (Muslims, Interview 17, Ribnovo 2005)

M.L.: Does that mean that there are Christian dzhins and Muslim $d z h i n s ?$

Ajshe: Of course there are, how could there not be?! You're a Christian, and I'm a Muslim. You get this kind and that, both kinds, there are different kinds of $d z h i n s$.

478 An earlier version of this text was originally published as an article (Lubanska 2009a).

(cc))BY-NC-ND $(C 2015$ Magdalena Lubanska

This work is licensed under the Creative Commons Attribution-NonCommercial-NoDerivs 3.0 License. 
M.L.: So, say, when somebody gets sick, that could have been caused by a Christian $d z h i n s$ or a Muslim dzhins, is that right?

A.: Yes. (Interview 4, Ribnovo 2005)

Fearful, awed and helpless in the face of jinn and samovilas, people consult healers of the other religion. My respondents take it for granted that an expert in Christian samovilas/jinn knows nothing about Muslim jinn and vice versa, similar to a doctor trained in a narrow range of conditions:

M.L.: Do Muslims ever seek healing from priests?

F.: When somebody "urodisa" [i.e. when one gets affected by harmful magic - this is a local dialect equivalent to urochasa in standard Bulgarian - M.L.], when all their medicines turn out to be useless, they will go to a priest. And the priest will write for him.

M.L.: What does the priest write?

F.: The priest consults some kind of books... and writes something. They visit priests as well. If somebody gets something, urodisal. They consult all kinds of people, and if the medicine doesn't work, they have no other choice but to visit the priest.

M.L.: So that's why [they] visit [priests]?

F.: Well, sometimes they catch something. When a man urodisa because of such a $d z h i n s$, he will go.

\section{M.L.: What kind of $d z h i n s ?$}

F.: There are Christian dzhins, and Muslim dzhins. In the same way, your Bulgarians visit hodzhas. (W, M, Interview 12, Ribnovo 2005)

Spurred by a fear of the other religion's demons, Muslims and Christians have formed a system of co-operation. Ordinary Christians or Muslims seem to treat the means of both religions as alternative paths to healing, even if seeking healing from the other religion is always regarded as a measure of last resort. When a health problem cannot be resolved using the means of one's own religion, they conclude that it has been caused by the other religion's demons:

Man H.: When in need, they call for a hodzha. When somebody gets sick, or maybe his child or wife. They come looking for hodzha, and we... look for priests. That's how I see it.

Woman A.: They search high and low, looking for hodzhas, looking for priests.

Woman F.: We have to delude ourselves somehow... (Muslims, Interview 29, Satovcha 2005) 
According to my respondents, it takes specialized know-how to understand the ways of such creatures or to ward off their deleterious influence. Unlike the healers themselves (hodzhas and priests) they attribute effective healing to technical competence rarther than personal trust in God. Such competence involves mastery of specific language skills (Orthodox church terminology for priests, the original Arabic of the Qur'an for hodzhas), and the knowledge of suitable formulas (verses from the Bible or the Qur'an), or, in the case of female healers, of specific charms (bayaniya or healing incantations) and other magical procedures which are incomprehensible to the uninitiated. Also very popular are various talismans (mostly containing Christian or Muslim prayers) with apotropaic and healing functions. Besides fear, a fascination with otherness in matters of religion seems to be another reason why some Muslims visit priests, and some Christians consult hodzhas. The other religion's sacred sphere may be fearsome but in critical moments it also seems more potent and effective than the more familiar variety.

Co-operation between Muslim and Christian healers, who are often representatives of religious elites, was noted by Frederik W. Hasluck as early as the 19th century: "Christians, and frequently even priests, when ill, invited emirs and dervishes to 'read [prayers - M.L.] over' them, while Turks frequented Christian priests for the same purpose. ... Christians, when they suspected the hostile working against them of black arts, possibly or probably put in motion by Moslems, resorted to Moslem incantations to avert or overcome them" (Hasluck 2005, p. 77-78). In my field research this was usually limited to visits to a healer of a different religion rather than adopting the other religion's prayer formulas or charms [bayaniya]. The single exception from this rule was an old woman from Garmen named Deshka, who learned a magical formula from a Pomak woman from Ognyanovo, almost ninety at the time, whom she had previously consulted on several occasions.

The formula Deshka learned from the Pomak woman should not be spoken out loud. It is used when casting led to rid a sufferer from "fright" [Bulgarian: uplah]. She does not know the meaning of the formula except for one word - kesebet ${ }^{479}$ - meaning "all things have been ruptured":

D.: Well, how should I know, it's Turkish. I say those words but I don't know exactly what they mean. Again, the meaning is that all evil things should go away.

M.L.: And it's all in Turkish?

D.: No, the one with the egg is not in Turkish. That one is in Bulgarian.

M.L.: Is that all, those formulas for casting lead? Aren't there any more?

479 Presumably from the Turkish kes, to cut. 
D.: Those are all: Besmenli tebet eda habil. Habit anyo manyo kesebet ${ }^{480}$. Those are the words (...).

M.L.: What does it mean?

D.: Kesebet means that all things have been ruptured. (W, Ch. Interview 36, Garmen 2006)

Ayshe, a popular female healer in Ribnovo, says that casting lead is also effective against the evil eye and jinn. She is open about the procedure in which lead is cast over a sufferer's body: the casting is repeated three times and takes place at dawn for three consecutive days. Once the lead has been cast it must be thrown in a river to make sure the ailment or "fright" (uplah) floats away:

A.: When you're casting lead you're chasing them [jinn - M.L.] away, they flee the casting. (W, M, Interview 4, Ribnovo 2005)

A.: The lead is cast here. This holds the water.

Sh.: First you melt [the lead] on the cooker.

A.: You hold it over the head. When I grab hold of a child I pour it over its head. Then over its heart and arms, and finally over its legs.

M.L.: And the fear will go away?

A.: The fear will go away. Three times. Three times, only in the morning, before the shepherds take the animals out [to pasture] ... On the fourth day you take the lead and pour it into the river so it can float away. (Women, M, Interview 4, Ribnovo 2005)

M.L.: How many times have you driven them away? Enchantments caused by $d z h i n s$ how many times have you gone to dispel them?

M.: My dad caught on on a different occasion. I took him to a baba (old woman) in Ognyanovo to have lead cast [over him]. The lead helped. That was about 10 years ago. (W, Ch, Interview 48, Garmen 2006)

The condition called urŭm or urama (which is caused by jinn or samovilas) is very different than an ordinary urok or evil eye $\mathrm{e}^{481}$ caused by a normal person - the damage caused by an evil eye, though dangerous, is seldom comparable to that caused by demons:

480 The Turkish formula has been corrupted to the point of incomprehensibility, which obviously does not take away from its effectiveness. On the contrary, the charm seems more potent on account of its incomprehensibility.

481 The literature refers to this as a belief in "the evil eye" (for instance, cf. Dickie 2008), a term my respondents tend to use in the plural (evil eyes, Bulgarian loshi ochi). Notably, the term suggests that the fear is aimed at an impersonal force rather than a concrete person (cf. Dickie 2008, p. 12), as if the adverse outcome was caused by feelings of jealousy rather than any deliberate human activity. 
K.: No, no! Uroki are not caused by dzhins.

M.L.: Are they caused by a human?

K.: As they say, ill time, evil eyes... (W, Ch, Interview 37, Garmen 2006)

D.: The eggs are a different thing. You use different words when breaking eggs. Eggs are used against urŭm.

Mariana Darska: Against uroki?

D.: No, not against uroki.

S.: It's called urŭm.

M.D.: What does it mean?

S.: Well, it means a person urŭdisa. That's what we say when $d z h i n$ does something.

D.: Say, you step on something and... (Women, Ch, Interview 36, Garmen 2006)

Urŭm usually involves a serious medical condition (mostly stroke or paralysis) and results directly from stepping onto a place occupied by jinn or samovilas, leading to a range of outcomes, from temporary indisposition to terminal illness:

M.: Well, those are samovilas, a banichka is enough to send them flying and the sufferer is freed. I felt weak for three or four days.

M.L.: Why?

M.: Because of samovilas.

M.L.: What happened to you?

M.: Well, I had a fall. I went to the toilet, I was about to squat down to pee, and it felt like somebody shoved me. I fell and I hit my lower back really hard, I fell on the floor. My head hurt terribly. I wanted to go to the kitchen and make some food but I couldn't. (W, Ch, Interview 48, Garmen 2006)

Such incidents are unavoidable if fated to happen, but they can sometimes be remedied:

M.: God made samovilas and he made medicine [against them - M.L.]. That's why they say that with any luck you'll come back to life and find a medicine. If not, you pass away. (W, Ch, Interview 34, Garmen 2006)

Although neither the Muslims nor the Christians in the area under discussion are prepared to regard the two religions as equivalent paths to salvation, they believe that 
each has a real connection with supernatural spiritual beings capable of impacting the human world.

Jinn are seen as creatures created by Allah before people. Jinn used to be much taller than men (up to 8 meters in body height) and, like people, they were created to serve God. According to the hodzha quoted below, traces of their habitation can still be found on earth, such as the pyramids in Egypt:

Hodzha 1: Before people settled the Earth, it was inhabited by three kinds of $d z h i n s$ who would reach a high point and were then destroyed. Those pyramids in Egypt that people talk about, as well as all of Damascus, were built on [the location of] a certain large city which used to be inhabited by beings seven or eight meters tall. (Interview 6, Ribnovo 2005)

Like people, jinn are sexual beings capable of feeling thirst and hunger. Jinn reproduce, they have free will and, despite living to a great age, they are mortal creatures. Some jinn live in accordance with the Qur'an (72: 1), some follow other religions, and some have become servants of Iblis. It is not clear whether non-believing jinn are the same thing as devils or perhaps a distinct type of spiritual beings:

Hodzha 1: I mean, we are talking about satans, satans is what we are talking about. A dzhin is a Satan, one of the non-believing ones who mean harm to people.

M.L.: Does that mean that dzhins are satans?

H.1: Yes, they are dzhins infidels. (Interview 10, Ribnovo 2005)

Woman S: Dzhins are of the masculine sex.

Man H.: Do dzhins attack Christians as well as Muslims?

Woman M.: They walk among people, you can’t see them. They're invisible.

M.L.: Are they everywhere?

M.: They're everywhere. If you happen to step on one, they take cruel revenge.

M.L.: Why do they take revenge? It's not like you stepped on them on purpose, is it?

M.: Still, you did step on them.

H.: Do you know anyone who can see them, recognize them?

M.: Nobody can see them, they're invisible. They find a meal somewhere, they're having lunch. (Christians Interview 48, Garmen 2006) 
Although the Qur'an explains that jinn have no knowledge of the supernatural world and cannot foretell the future (34: 14$)^{482}$, they are credited with such skills in the Rhodopes. The local population believes that jinn aid fortunetellers and healers with their powers. The most effective measures against the destructive power of jinn can be provided by dzhindzhiyas, known for their ability to help sufferers from demonic possession or other health problems caused by jinn.

The hodzha from Ribnovo told me about his healing methods in cases of possession by a jinni: the basic procedure involves reading the Qur'an in Arabic (using certain versus best suited for this purpose), but he also uses other methods, such as starving the jinni. The starving does not affect the sufferer: the act of saying the basmala $^{483}$ before a meal is enough to render the food useless for the jinni's purposes (Interview 10, Ribnovo 2005).

The same hodzha explained to me the distinguishing features of jinn, such as the ability to cover enormous distances in a matter of seconds, invisibility or shape shifting, changing mostly into animal forms (snakes, mice, taught as is, cats or dogs) but also into humans:

Hodzha 1: In their proper form they look like small animals with tails. (Interview 10, Ribnovo 2005)

Although jinn have supernatural powers, the hodzha believes that they can be discovered using one of their many weaknesses, such as their inability to travel along a curved line or take on a perfect semblance of the human shape (for instance, a jinni's handshake may feel rubbery as its hand contains no bones).

The fact that jinn are solid in appearance only is another distinguishing feature, and it is possible (though certainly not recommended) to walk clean through a jinni. Despite their supernatural powers and intelligence, said the hodzha, jinn are reminiscent of 12-year-old children in terms of their mental processes. This is why another of his methods of driving out a jinni is to ask it a series of tricky questions designed to manipulate and confuse the adversary.

Although many Muslims were able to provide detailed explanations of jinni behaviour and characteristics, they almost never provided descriptions of their

482 This relates to prophet Sulayman's death, an event mentioned in the Qur'an: when the jinni saw Sulayman standing, supporting himself with his staff, they did not suspect that he was dead: "And when We decreed that he should die, naught indicated to them that he was dead but the Beast of the Earth devouring his staff; and when he fell down, the jinni saw clearly that, had they only known the Unseen, they would not have continued in the humbling chastisement" (34: 14).

483 A Muslim prayer formula, bi-smi Allahi al-Rahmani al-Rahim, "In the name of God, the Most Gracious, the Most Merciful”, which opens each Surah except for the ninth as well as any text written by a religious Muslim; Muslims should use the formula when starting new work (Danecki 1997, p. 48; Dziekan 1997, p. 20). This suggests that dzhindzhiya hodzhas also use it as an apotropaic formula. 
appearance. Similarly, my Christian respondents never discussed the appearance of samovilas. At first I assumed I had failed to ask the right questions but on my next field trip I was informed that the beings are invisible, and therefore impossible to describe (Interviews 34, 48, 54, Garmen 2006-2009).

Nearly all respondents had stories involving first- or second-hand accounts of people suffering as a result of entering locations occupied by jinn or samovilas, mostly as a result of unintentionally stepping or urinating on a jinni table set for a meal (trapeza, sofra). There is a belief in the Rhodopes that jinn inhabit "unclean" places (such as bathrooms or toilets), but also rivers or springs (Boneva 1994, p. 37), caves, underground rooms and passages, cemeteries, ruins or rubbish heaps (Garnett 1909, p. 134; Troeva-Grigorova 2003, p. 190-191) as well as balks (boundaries at the edges of fields belonging to different people):

Turkish Woman: Say, you're out on a field somewhere ... Here's your field, here's mine. If you pee in the middle, you may get jinxed by dzhins. When that happens, you have to seek help from hodzhas. Every time you pee somewhere, you have to spit and say bi-smi Allahi al-Rahmani al-Rahim. And the $d z h i n s$ will flee. (W, M, Interview 45, Dabnitsa 2006)

My respondents claimed that such supernatural beings became active after dark and at night, and liked to stay close to people having meals. For this reason it is not advisable to leave food unattended around dusk and finish it afterwards, at least not without first saying a prayer invoking the name of Allah. This is regarded as a protective measure to safeguard people from harm potentially caused by jinn. Other vulnerable activities include napping or bathing after dark (at time of the day which Muslims call aksham ${ }^{484}$ (Turkish: akşam, Arabic: al-maghrib):

M.L.: When do the dzhins come out?

Bula: When the sun sets. As soon as the sun sets, as soon as it gets low in the sky they start coming out.

M.L.: Why?

Bula: Because those who are outside at the time ... because Allah does not permit people to be loitering in the streets at that time. Those who go out at this time will encounter them. (Interview 13, Ribnovo 2005)

A female respondent narrated a story of her father who experienced uram because he recklessly removed his sash and placed it on a samodiva table before going to the toilet located in an outhouse:

484 The time between sunset and the moment the horizon becomes no longer visible; one of the five obligatory prayer times in Islam. 
M.: He said, when he removed his sash, he left it on a table used by samodivas.

S.: Dzhins. (...)

M.L.: Are $d z h i n s$ and samodivas one and the same thing?

S.: Yes. (...)

M.: There was a heap of stones behind the toilet, and he had his lower back wrapped in a very old sash because he was suffering from a back pain. He unwound his sash and went to the toilet, he came out, he wrapped the sash around his waist and walked upstairs back into the house. Suddenly he cried, "veeee, veeee, veeee" and he fell to his left side. His eyes were upturned, he looked terrible ... He was foaming at the mouth, his lips were twisted. Mother called from upstairs, "Todore, go and fetch a doctor to see him, he's not looking well”. The doctor said he wouldn't recover, that he was done for, he was on his way out. Then they looked for the women, the old women in the village who break eggs. (W, Ch, Interview 34, Garmen 2006)

As this passage suggests, medical assistance was sought first, followed by a healer belonging to the same religious group, followed by a healer of a different religion (a dzhindzhiya hodzha). "When you're in need," my respondents said, "it doesn't matter who does the helping, a priest or hodzha," and "it's not clear where the help will come from".

The female healers tried to help sufferers using an egg-breaking ritual (Bulgarian: troshene na yaytse). The ritual involves swirling water in a vessel and uttering a special formula:

D.: "We ask you nine times to tell us what it is you've ruptured so we can offer an egg as kurban". Then, you bring an egg, and I break it and put it in a bowl of water, and I [swirl] the egg around like so, after I put it in the bowl and [I say]: "We ask you nine times to tell us what it is you've ruptured so we can offer an egg as kurban" - three times. I break the egg, and you have to make the sign of the cross [cross your arms] three times, and out it comes. After I break the egg I put some sugar and basil in the water, I dunk both in the water and say [the formula] again. (W, Ch, Interview 36, Garmen 2006)

The shape of the broken egg in sweetened basil water imitates the shape of the sufferer and identifies the location where the problem first occurred:

M.: I knock the egg, I knock it against [the side of the] bowl and the egg dissolves in the water, the way the man lay. The white spreads [to form a shape] like the body of the lying person, [and shows] where he urodisal, what happened to him. You call the egg kurban... for those samovilas. That's what happened to him.

\section{M.L.: For samovilas?}

M.: For the thing that afflicted him. We call that samovilas. (W, Ch, Interview 34, Garmen 2006) 
D.: I tell them to put an egg under the pillow and keep it there overnight. When they come, you break it. That's how...

M.L.: That's how you can tell where it happened?

D.: Right.

M.L.: But it's not like anyone can tell?

D.: Even I can't tell exactly any more, but the problem goes away. When they come the problem goes away. I can tell with some people, but with others, not quite. (W, Ch, Interview 36, Garmen 2006)

The egg is referred to as a kurban for the samovilas or jinn that have been inadvertently crossed, and is believed to be an effective health restorative. However, the kurban offered to jinn or samovilas must also contain a sweet substance (honey of sugar):

S.: My godson, you wouldn't believe how much help he was! That's right, with his egg-breaking. He was quite an expert. He would say, "You've been struck by a dzhin", he called that uram. He would tell you exactly where it happened.

M.L.: And you had to go and do something there?

S.: When he broke and added the egg, you throw away the egg, add sugar, and throw that away, too.

M.L.: Something sweet?

S.: Something sweet, honey or sugar. This brings healing to a lot of people.

M.L.: Why sweet things? Do they eat something sweet and calm down?

S.: That's what people say, sweet things are important to them. (W, Ch, Interview 35, Garmen 2006)

M.: I had some honey, and I sprinkled that place where I'd had a fall. Two days later I recovered my strength. (W, Ch, Interview 48, Garmen 2006)

\section{I heard a similar account from a Muslim woman from Dabnitsa:}

Turkish Woman: Yes. Absolutely. Mother told me, if you know where you'd peed, place a sugar cube there, and say, "Come $d z h i n e s$, take this sweet and give me the bitter". I got jinxed like that once.

M.L.: You did? 
T.W.: That's right, I went ... oh, that was really terrible! Later I came back and left them a sofrichka [meal], that's what you call it, I threw some sugar on the ground and came back by a different route.

M.L.: Did it help?

T.W.: It did. (W, M, Interview 45, Dabnitsa 2006)

If the ailment disappears after kurban is left for jinn/samovilas, egg-breaking is no longer needed:

M.: Well, when I had a fall in the toilet [I hit myself] here, right here. Something just whacked me good. I came here, I spent a day in bed and Kalinka took me to the garden for three days. Then I came back. When I was still at their place it occurred to me, why not sprinkle the place with some honey? So, when I came back, I sprinkled some honey where I had my fall.

M.L.: Why did you do that?

M.: It helped me. (W, Ch, Interview 34, Garmen 2006)

Where the misfortune (mental or physical illness) is caused by jinn of the other religion, effective aid can only be provided by members of that religion. The family of the man who unwittingly put his sash on a samovila table consulted a dzhindzhiya, who saw the man and recommended a series of activities to placate the angry jinn. The hodzha recommended that three matches should first be lit where the man fell, then he told the family to sew together three sheets of paper containing Muslim prayers (muska/amalichka/amaliyka) to form a kind of paper sash, to be put on over the sufferer's head and worn for three days for apotropaic purposes. After this period, the belt should be discarded in moving water ${ }^{485}$ :

M.: And then, those pieces were sewn together at each end, and he wore it over his shoulder for three days. After three days [the hodzha] said, "take that and throw it into the river so that water can carry it away".

M.L.: And those were muskas?

S.: Yes, it's called a muska. An amalichka or a muska.

M.: Amale.

M.L.: What does it actually mean, amale?

485 According to M. Georgiev, inhabitants of the Rhodopes, "when they cannot locate a magical object [which causes the illness - M.L.] they consult a hodzha, who gives the sufferer three muskas: one is sewn to his clothes as an amulet, one is burned and used as incense to fumigate him, and one is soaked in a glass of water which the sufferer then drinks" (Georgiyev 1994, p. 64, translated from Bulgarian). 
M.: Well, it’s that folded piece of paper you carry with you. And you sew a sash...

S.: Danko told her, "Mother, go to the bridge and throw this into the water, water will carry it away". And she did, she threw it away. When we did that, dad recovered. (W, Ch, Interview 34, Garmen 2006)

According to my respondent, the intervention produced a recovery. The amalichkas successfully drained off the "bad energy" which had entered his body via the sash jinxed by samodivas/jinn. The object must be worn for three days, perhaps an echo of the popular belief that samodivas eat meals in groups of three, so each samodiva must be warded off in turn for recovery to happen.

Practically all of my Christian respondents had first- or second-hand experience of hodzhas or female Muslim healers being consulted in the family:

E.: Her sister came to her in the morning to wake her up and saw her just staring at the ceiling, her eyes open wide, she wasn't even blinking. No reaction. For twenty days. They transferred her from Gotse Delchev to Blagoevgrad. She received medical attention and so on, but when you're in need you take people's advice and go where they tell you. She heard about a hodzha and went to him, and he told her, "This is how it happened, in these pillows". She said, these are my mother-in-law's pillows. That means somebody hurt her mother-in-law with magic. (W, Atheist from Christian background, Interview 37, Garmen 2006)

Sometimes a female healer will recommend a visit to a priest or a hodzha when unable to provide effective aid. Some of my respondents make their decision based on a form of fortune-telling involving the use of matches:

Orthodox Priest: When they go to a hodzha, that hodzha will sometimes tell them, "It will take a priest to solve this problem".

\section{M.L.: In what cases does that happen?}

P.: I don't know. I simply don't know hodzhas and I don't know how reach a decision like that. They have needles, some kind of needles. They place needles to indicate who should be consulted, a hodzha or a priest. But I have no idea how they do that. (Interview 50, Garmen 2006)

When asked why they consult hodzhas in emergencies, my Christian respondents mostly explained that hodzhas had a special book (the Qur'an) containing healing formulas. The fact that the formulas are incomprehensible to the respondents is immaterial, and they have no desire to discover the meaning of the words. Most Christian "patients" are only interested in the medical outcome, and they have no wish to master such formulas to use them in their own group. This is why their stories of such visits contain vague references to "a kind of book" or to the writing of "some kind of squiggly lines". At the same time, the very mysteriousness of the methods used by the members of the other religion seems to produce a fascinated belief in their effectiveness: 
M.L.: Why do you think the hodzha knows more about samovilas?

M.: He has the Qur'an and reads it. He has a kind of book, a very thick one, and reads out of it. You tell him what your problem is, and he leafs through the book and reads out of those leaves. There's no telling what he might be saying. We don't know. The main thing is, that man helped us. (W, Ch, Interview 34, Garmen 2006)

M.L.: Who gets consulted in emergencies? I’ve heard something about amalichkas...?

D.: People visit the "odzha” [hodzha]. I used to go to an odzha, too. My dad got very ill. The odzha is from [the village of] Oreshe but he lives in town. In the past he worked as a shepherd for my grandfather. I went to him and asked him to come and see my dad, who was in really bad shape. Would he live or die? He wrote something and says, if the number is even he will live. If the number is odd, he will die. I don't even know what he wrote there.

M.L.: Was that letters?

D.: Some kind of squiggly lines, there's no telling. Then he [the respondent's father] stirred to life for the first time. "He’s going to live,” he said. “But I don’t know how long.” And we came back. Dad is very ill but he got better. He lived for three more years. (W, Ch, Interview 41, Garmen 2006)

M.L.: You're not the first person telling me about a hodzha from Oreshe. Is that one person? Was he consulted by a lot of people?

D.: Oh yes, he was!

M.L.: What is his name?

D.: Well, it’s Ali “odzha”.

M.L.: Is he alive?

D.: I don’t know if he is still alive but he had a kitab and read out of it.

M.L.: You mean, he wrote amaliykas?

D.: No, he didn't. (W, Ch, Interview 41, Garmen 2006)

Similarly, Christians consult female Muslim healers who use "all kinds of little sheets of paper" or "[talk] inaudibly in [their] language", and make familiar gestures such as "spreading honey" over the sheets of paper, reminiscent of the Christian practice of placating samodivas with sweets:

Woman K.: I can tell you what they do because I went to an old Muslim woman once. I actually went there to seek help for a specific problem. I needed help with pain and adverse magic and jinxes. She has this... She produced a shoebox filled with all kinds of little sheets of paper, and she began. So, say, first I tell her I was frightened, that I have this fear or anxiety. And she puts honey on a little piece of paper and starts talking inaudibly in her language. I don't know exactly 
what she said. And she tells me, "You've drunk a dzhin who was sleeping in water" or "A shadow is coming your way and it treads on your body".

M.L.: What do you mean?!

Man H.: She doesn't explain.

W.K.: She doesn't explain what it might mean.

Woman E.: She says, a shadow. But she won’t tell you what kind of shadow.

K.: It's called a morava in Bulgarian. She told me, "A morava is treading on your body" and you're getting bruised, you get those little spots on your body. Then they say "A morava is treading on your body". That's what I heard from the grandmother. You never bumped into anything and yet you get a bruise. Then they say, "A morava has tread on your body". That woman said, "A shadow is treading on your body, a shadow is coming into your room" ... No, it's not $d z h i n$, but the old woman gives you a little piece of paper and says, "Hide this piece of paper in this place or that, and pour some rakiya into a glass. Just sit there and keep pouring more as it disappears...”

M.L.: Somebody drinks it?

K.: Yes.

\section{M.L.: A dzhin?}

W.K.: No, a ghost. (W.K \& M.H, Christians; W.E., Atheist, Interview 37, Garmen 2006)

Woman K.: Well, she makes muskas. She says, “It's here”... But she doesn't write on it, unlike hodzhas, as far as I know. All she does is say something to herself, she tears out a small sheet of paper for them and says, "Here, carry this with you. Have no fear, everything's alright". But there's no writing on the paper, like a name or prayers from the Qur'an.

M.L.: Well, what do you do with that?

W.K.: Different things. That depends on its purpose. You can throw it into moving water or throw it away, or carry it with you for luck. (W, Ch, Interview 37, Garmen 2006)

In the same way, Muslims describe priests writing down "some kind of prayers" or "tossing a kalimavka over a baby" to stop it crying:

Turkish Woman: My daughter cried a lot so I went to a fortune-teller [gledachka] who told me to see a priest and have him toss a kilimyavka [a kamelaukion, a tall brimless hat worn by priests M.L.] three times to help with the crying.

M.L.: Did it help?

T.W.: Yeah.

Mariana Darska: Where does he [a priest] toss the kilimyavka over a baby? 
T.W.: Yeah.

M.: Was she lying down when he did that?

T.W.: Yes.

M.L: Does he say any prayers?

T.W.: He does. (W, M, Interview 45, Dabnitsa 2006)

Within certain limits, priests and hodzhas see nothing wrong in healing members of a different religion with the tools of their own religion, even less orthodox ones such as tossing kamelaukion hats over babies. The limits mainly relate to the form and scope of the prayers said over members of a different religion and the protective (apotropaic) items, which priests and hodzhas treat as quasi-sacramental objects. For instance, some hodzhas refrain from giving paper slips containing passages from the Arabic Qur'an to Christians for fear that they might commit sacrilege against the holy words of Allah:

M.L.: What do they have to do to receive help? Are there any conditions?

Hodzha 1: I mostly make those things, and I give them to those people for water-related things [rituals involving water]. Then I follow certain procedures here because you can't write [passages from] the Holy Qur'an, the authentic source, for people who don’t believe in it ...

M.L.: You mean, they can't carry [passages from] the Qur'an with them? You wouldn’t offer it to them?

H.1: No. They have to be cleansed for that. The Qur'an is not like any old novel that people can hold in their hands like that. You have to make preparations, perform suitable ablutions. If you're not a Muslim you need to go through the ritual, wash your hands and prepare to hold a holy book. That's why I'm reluctant to give it to them. I keep it for myself.

M.L.: You mean, you don’t give them any material objects?

H.1: I don’t give them anything. (Interview 9, Ribnovo 2005)

Fearing sacrilege and mindful of the need to preserve ritual purity around the written text of the Qur'an (whether in its entirety or with individual passages), the hodzha is reluctant to write passages from the Qur'an not just for Christians but also for Muslims. As it turns out, some Muslims worship the Qur'an in itself as a talisman ${ }^{486}$ and not as the Word of God:

486 I use the term "talisman" rather than "amulet”, because "talismans, unlike amulets, have written words or at least letters inscribed on them” (Kieckhefer 1990: p. 77). 
Hodzha 1: I'm reluctant to write things down for Muslims to carry around. As a rule, I avoid giving people amulets or talismans. (Interview 9, Ribnovo 2005)

This stems partly from a fear of profanation (for instance, where a person carrying an amaliyka forgets to remove it before entering an unclean place like a toilet), and partly from what the hodzha sees as a heterodox tendency to regard such slips of paper as talismanic instead of seeking help from Allah alone.

For this reason, the hodzha prefers to mostly read the Qur'an over water to endow the water with healing properties, or to dunk in the water sheets of paper containing passages from the Qur'an. A chance to wash one's body in this kind of "blessed” water appears to meet a very real sensory need in the sufferers without losing control over the proceedings as the hodzha can supervise the sufferer's interactions with the holy object:

Hodzha 1: I only help them using writings in water.

M.L.: What does that involve?

H.1: You write things, and read them out over some water, or you dunk your writings in the water.

M.L.: Aren’t those passages from the Qur’an?

H.1: That, too.

M.L.: So, what exactly do you do over that water?

H.1: You read passages from the Qur'an, sometimes you blow on the water, when you read certain [Surahs] such as 33 , or 35 , or 37 , or 11 , depending on what it says in the books. Or you write something, throw it in the water and then use the water to wash your face, your forearms, or you drink it. You can't use that water for washing your entire body. You can't do that with passages from the Qur'an.

M.L.: So, to put it in terms understandable to Christians, that water becomes holy?

H.1: Yes, precisely. This water, as a general rule there are many recommendations from Allah, mostly passages relating to disease. A lot of the time they're effective.

M.L.: Is it okay to use such methods to help Christians?

H.1: It's not about Christians as such, it's more general. For the most part you help believers, people who believe in God. With those who don't believe in God, it's rare, practically unheard of. When you finish the procedure you say, you say the words of the Highest. A person who believes in the Highest may recover. But if he has no faith, things get terrifying. This goes on in an unchanged form. (Interview 9, Ribnovo 2005) 
Orthodox Christian priests make small modifications to the wording of prayers said over members of a different religion to replace the phrase "God's servant" with the phrase "God's creature". They may also hold a service to the mother of God or recite Psalm 90 for a non-Christian:

Archimandrite Grigoriy: I mean, with a Christian you can perform a blessing, a maslosvet [holy unction - M.L.] for the seriously ill, to anoint them. You can also hold a service to the Mother of God and mention them in the service, and so on.

M.L.: Which book do you use for the service?

A.G.: The Trebnik, but there are also services in the Chasoslov ${ }^{487}$. Or in the Hermeneia ${ }^{488}$ for the month of August. In practical terms this is the canon of the Holy Mother of God, a prayer canon, paraklis. There is a Greek word, paraklis, meaning pleading, imploration, that's where it comes from. And that's something we can do. There are also more general prayers for healing, except we change the wording, for instance where it says "your servant", meaning the servant of Christ, which we replace with "God's creature", because they are not servants of God. You become a servant of God through baptism. They do not practice baptism, so [a Muslim] is God's creature but you couldn't describe one as “God's servant”. (Interview 27, Satovcha 2005)

The Metropolitan of Nevrokop recited to me the following prayer spoken for unbaptised people:

Metropolitan Natanail: God. Christ, Son of God, who came to save the world, bless this your creature, hear our prayer. That's it. (Interview 62, Hadzhidimovo 2009)

In other words, the ministrations of a priest cannot be as effective for Muslims as they are for Christians. Accoring to the bishop, unbaptised people are God's creatures but they are not God's servants whose names are entered in the book of life. Certain prayers, such as exorcisms by St. Basil, are only available to Christians, and cannot be used for members of a different religion without prior conversion to Christianity. However, such cases are sporadic and do not seem to be part of a deliberate proselytizing policy on the part of the local clergy, especially since the prayers are explicitly motivated by purposes of healing rather than conversion:

M.L.: Do they ever convert to Christianity?

Archimandrite Grigoriy: Unfortunately, that's very rare. In my time in the monastery [of St. George in Hadzhidimovo - M.L.] we've only had two such cases.

M.L.: Did they convert after experiencing healing, or was that unrelated?

487 Greek: horologion, liturgical book with the fixed portions of the daily cycle of prayers.

488 An icon painting manual. 
A.G.: There was a girl who was in very bad shape, you could say she was possessed. And we made it clear that the prayers of Basil, and everything, can’t be used for Muslims. And she said, "We'll have the child baptised so he can do that". And she recovered. Her mother later came to tell us that [the daughter] have got married and started a new family. (Interview 27, Satovcha 2005)

Some priests come up with alternative solutions in such cases: where it is not possible to say certain prayers over a Muslim they encourage the sufferer to leave a gift or say a private prayer. One of my female Christian respondents witnessed a situation like that:

Y.: There was a sick child, and its mother wanted a priest to sing prayers over it if he could. But if he did that the child would lose its religion. I personally went to ask the priest, I said there was this sick child, a little Muslim child, and could he please sing over it or simply say a prayer for its health. He said, no. He can't do it because the child is not baptised. "That's why," he said "it needs to be baptised first before this kind of prayer can be some over it. And if you baptise the child it has to give up its religion". So I went and explained everything to its mother, and I say, “This can't be done. The priest said it was enough for her to leave a gift, and he promised to pray to our God for its recovery, but he can't sing any prayers over the child”. And she chose to leave some money and say a private prayer. I said, “Do you want our God or your Allah. It's your choice. But we can't do that," I said, "because the child is not baptised. If it gets baptised it will give up its religion”. Then she asked me to go to Pamporovo and ask the people in the same church. She said, "Go and ask this other priest, too". And the priest said the same thing to us, including her, how he couldn't do that. (W, Ch, Interview 28, Satovcha 2005)

The bishop also said that Muslims carry slips of paper around their necks containing a Christian prayer precisely because priests cannot say such prayers over them in person:

M.L.: Are those prayers taken from Trebnik or...?

Metropolitan Natanail: Some are from Trebnik, that depends on the case. But you leave out the name. [You write] here this prayer for the sake of your creature.

M.L.: You mean, when writing a prayer for a Christian?

M.N.: No, no. Christians don't wear prayers. You pray over them. But they [Muslims] are not baptised so we can't read out prayers over them. That's why we write them instead.

M.L.: So it’s just “your creature” [Bulgarian: tvoe sûzdanie]?

M.N.: Yes, because we are all God's creatures. And when you get baptised you become a person, and your name gets entered in the book of life. (Interview 62, Hadzhidimovo 2009)

Orthodox Priest: An Orthodox Christian priest writes [prayers] for Muslims. In general, we just read out prayers for Christians here in their presence, or if they're absent. They write them down and give them to me, and I say the prayer later. (Interview 50, Garmen 2006) 
As it turns out, the practice involves more than simply stepping to offer help to members of a different religion. It may be a symptom of mimetic rivalry ${ }^{489}$ which under the influence of "Adat Islam" additionally "boosts" the popularity and value of writing talismans containing texts of prayers, a practice already known in Bulgaria in the Middle Ages ${ }^{490}$. It seems like a new meaning is added to the practice: the slips of paper containing Christian prayers worn as an apotropaic measure are not only functionally equivalent to amaliykas ${ }^{491}$, but also resemble them visually in that they are handwritten passages of sacred texts worn around one's neck. I never heard from my respondents about any other types of talismans being used in the area. The written Christian prayers are not only a response to the Christian interest in Muslim amaliykas, but also provide help to Muslims in a form they recognise as familiar. From their perspective, the priest's gesture could be interpreted as receiving a "Christian amaliyka" which they request and their own talismans fail or when so directed by the fortune-telling ritual involving needles:

M.L.: Do you ever get Muslims coming to ask you to pray for them?

Orthodox Priest: No, they don’t.

M.L.: Christians visit hodzhas more.

P.: Christians visit us more, and sometimes they visit the hodzha as well.

M.L.: But not the other way round, with Muslims visiting you?

P.: They come and we write the prayers for them. They call that amaliykas. Then we fold this [piece of paper] into a triangle and they wear it around their neck... (Interview 50, Garmen 2006)

In a longer interview it turned out that Christians, too, wore written prayers. Presumably, when Christians receive prayers from their priests, such as Psalm 90,

489 A desire to possess the kind of effective protection enjoyed by members of the different religion. In those areas were Christians receive equivalent items (such as pieces of paper containing Psalm 90), their mimetic rivalry decreases as they no longer desire amaliykas as an effective apotropaic measure. 490 As suggested by archeological finds of lead amulets containing prayers, suggesting that they were popular in many regions of the country in the Middle Ages. Their form and content are varied, containing texts from the 10th-14th centuries which, unlike those recorded in books, remained stable over than period (Popkonstantinov, Konstantinova 1995, p. 853).

491 This is the conclusion also reached in passing by M. Gruev and A. Kalionski (Gruev, Kalionski 2008, p. 43), although the problem is tangential to their book. It would seem necessary to examine the modern written charms from a historical perspective by comparing them with the medieval and later talismans and amaliykas (in terms of form rather than content). Such research should also tackle the problem of mutual cultural influence: for instance, did Islamic influence in religiously mixed areas affect and intensify the Christian practice of writing talismans? 
written down on pieces of paper or embroidered on belts, the priests may expect that at least some of them will not visit a hodzha to receive an amaliyka. In other words, we are dealing with a superficial syncretism which is in fact an undeclared strategy to attract "Muslim clients" and boost the stature of Christianity ${ }^{492}$ in Christian eyes. From the viewpoint of Christian clergy, the practice is adopted for the anti-syncretic purpose of discouraging Christians from seeking help among members of the other religion:

Archimandrite Grigoriy: Generally, the Bible is effective. The parts we use are Psalm 90 from the Psalter, some people read that. It delivers one from all evils. There are also... Some people also carry Psalm 90 on strips. It's written down and embroidered on belts worn by Christians. (Interview 27, Satovcha 2005)

At the same time, the priests interpret this kind of help provided to non-Christians exclusively in terms of Christian values, glossing over the implicit element of cultural survival strategy in a multicultural environment. According to Archimandrite Grigoriy, prayers for non-Christians, and even enemies, is in fact recommended, demonstrating the right attitude. He draws an analogy with the parable of the Good Samaritan:

Archimandrite Grigoriy: It's permitted, helping [non-Christians] is permitted, they are God's creatures [Bulgarian: sŭzdaniya Bozhi - M.L.] As a matter of principle, the Church cannot pray for suicides, but we don't discourage anyone from individual prayer for the souls of such people. All it takes is a willing heart and a Christian identity. Christ told us to pray for our enemies and do good not only unto our loved ones and friends, but also unto all the others. The Good Samaritan is an example. They had nothing to do with Judaism, they were pagans. They made sacrifices to mountain, a certain high mountain. And yet it was a Samaritan who stopped and offered help to a man in need. Yes, we mustn't forget Christ's commandment which says that all people are our neighbours and we cannot reject them, we cannot say "You're Muslims, this is nothing to do with you. We have nothing to do with you". This kind of behavior is characteristic of sectarians [cult members] or others who say "No, you're not one of us, we have nothing in common". Christians mustn't be like that. (Interview 27, Satovcha 2005)

Similarly, the Islamic religious elites consider it a moral duty to provide help to nonMuslims. Members of the Muslim elite read out to Christians and Muslims alike the last two suras of the Qur'an (113 and 114), which the angel Jibra'il gave to Muhammad when he fell victim to black magic.

Priests and hodzhas regard spiritual help to members of the other religion as their religious duty. They each regard themselves as God's agents and tools, and view their counterparts as magicians ${ }^{493}$ in league with dark forces. "But the appreciation

492 Obviously taken to mean a local heterodox form of the religion.

493 At the same time, the distinction serves to marginalize the other and to discourage the faithful from seeking help from healers of a different religion (cf. Janowitz 2001, p. 3). This distinction lies at the root of the concept of magic as "The Greek term mageia comes from the term for a Persian 
changes with the change of the standpoint, and no magic can be termed good or evil in itself" (Thomas, Znaniecki 1918, p. 220). Depending on the identity of the practitioner, the same practice may be regarded in relative terms as religious or magical activity ${ }^{494}$. Although at the level of declarations they condemn the use of magical practices as sinful, the practice does not always go hand in hand with the declarations. In everyday life, orthodox religious healing rituals (prayer) mingles with heterodox practices (using written prayers as talismans). Priests and hodzhas occasionally become "magicians" to boost their stature in the eyes of the faithful. In practices involving healing from demonic possession or jinxes and evil eyes, religion takes second place to the logic of magical thinking was certain actions predictably produce specific outcomes. Effective help in the problem at hand becomes more important than stickling for religious orthodoxy.

In the case of Christianity, helping non-Christians is treated as a duty towards one's neighbours in the religious sense; in the case of Islam, it becomes part of mutual obligations towards one's neighbours in the secular sense, a religious duty for which an individual must account in the next world during partial judgement held in the grave (see above). To Muslims, Christians are not only actual neighbours but also believers: People of the Book, Ahl al-Kitab.

From the viewpoint of the religious elites, the opposite situation (where believers seek help in the other religion) is more of a problem. In recent times the practice seems to be discouraged more strongly than in the past. My respondents say that even hodzhas used to come to Hadzhidimovo to seek healing, and they used to send people to priests when they were unable to help. Orthodox priests used to do the same:

M.L.: Do people tell you which problems should be solved by hodzha, and which should be solved by a priest? Are there any differences, do people simply know where to seek help for a given kind of problem?

G.: I mean, I've heard that members of the clergy tell you what to do. When I talked about it with my friends, they say they used to be situations where they went to visit a hodzha, and he would tell them, you were Muslims, but you must go to this particular monastery or to this particular church and priest.

M.L.: The hodzha would...

priest (magos)" (Janowitz 2001, p. 5) and “throughout Mediterranean antiquity the words mageia and magos, "magic" and »magician«, were used to categorize the exotic and the dangerous. They were foreign words to a Greek speaker, used to describe foreign practices semiotically joined to the word barbarian” (Meltzer 1994, p. 2).

494 The priest treats amaliykas made by hodzhas as a form of magic, but regards his own writings as a religious activity, and vice versa. Obviously, this is probably a simplification as each religious group will contain representatives of religious elites with a different opinion on the matter. 
G.: The hodzha would tell them to do that. But that was some time ago. Now I don't know, maybe the hodzhas have changed. (W, Ch, Interview 23, Satovcha 2005)

Currently, the religious elites tend to regard such practices as idolatry since they attribute the other religion's healing powers to magic and evil spirits rather than to an openness to God's grace. Like the local community in general, they do not deny that members of the other religion may have healing powers, but they consider such powers to be caused by demonic influence, potentially leading to perdition. In this logic, only their own religion "works with God"; members of the other religion are effective because they "work with the devil":

M.L.: Do Christians ever visit hodzhas?

Archimandrite Grigoriy: You could say there are such Christians, but to me they are not Christians. They’re Christians in their baptism certificates only ...

M.L.: You mean, you don't refer them to hodzhas?

A.G.: We can't refer them.

M.L.: To hodzhas?

A.G.: We can't refer them to hodzhas because we know that hodzhas do magic. It's supposed to be about warding off jinxes, but if you're removing jinxes you can also cast them. So, we know that the Old Testament that God commanded all fortune-tellers who summon spirits to be stoned. Already in the Old Testament you see God's attitude to the people he ordered to be stoned to death. Which means we mustn't even think that people who visit them could benefit in any way. On the contrary. (Interview 27, Satovcha 2005)

The local hodzha offers a mirror image of that statement from the archimandrite:

M.L.: Does it happen the other way around? Can a Muslim come to a priest or a Christian?

Hodzha 5: We've talked about this, it doesn’t work.

M.L.: The way I understood it, there are Muslim $d z h i n s$ and Christian $d z h i n s$, and that's why people..

H.5: Yes. There are.

M.L.: And that's why Muslims sometimes visit the priest because they don't know how to deal with those Christian...

H.5: Only the Qur'an can help with a dzhin. And you've got to be very religious, to have enough strength to repulse, I mean, to use the strength of the Qur'an to repulse the energy of the $d z h i n s . .$. To chase it out of the body that it's afflicting. (Interview 26, Satovcha 2005) 
In some cases priests or hodzhas discourage believers from visiting a healer belonging to a different religion. One of my female respondents followed this advice from a priest who came to her house and helped her with a vodosvet.

As healers and as figures of religious authority, priests and hodzhas are convinced that only prior and orthodox belief are effective in healing demonic influence. They attribute the healing to God's grace, of which they are agents, rather than talismans. They are not surprised to receive visits from members of another religion who feel lost, because they believe the other religion does not have the means to deal with the grave problem of demonic possession. They regard the opposite situation, where their co-religionists visit members of the other religion, as the sin: outsiders are believed to have no access to God, and their false religion can only be a tool of demonic powers.

Ordinary believers view these things differently, and consider the other religion's magical procedures is more effective than their own. However, this does not suggest religious syncretism, but rather fear and a hidden (perhaps unconscious) fascination with the sphere of the sacred in the other religion. Using the services of the other religion's exorcists or accepting their written exorcisms is believed effective precisely on account of its mysteriousness. This applies in particular to the words uttered or written down by such healers ${ }^{495}$, which must be incomprehensible to be credited with a special potency. This is why "in many mixed villages, Muslims get amulets from priests modelled on the Christian design, and Orthodox Christians prefer to go to a hodzha claiming that his muskas are more effective " (Hristova 2001, p. 28, translated from Bulgarian).

Neither the sufferers themselves nor their co-religionists regard visits to Christian priests or hodzhas as acts of apostasy. They are open to mutual assistance in emergencies caused by jinn or samovilas threatening to cause damage to body and soul, but neither Muslims nor Christians are interested in gaining a better understanding of the religious and magical rites. They accept their power for pragmatic reasons, but they keep them at an arm's length in terms of personal interests or enquiries, a solution which safeguards each group from religious syncretism.

Consequently, this cultural practice must be regarded as a superficial form of syncretism which does not produce a synthesis of Islam and Christianity. This syncretism is a cultural strategy developed by both groups in order to preserve each group's unique identity while acknowledging the other group's impact in daily life.

495 "Magic everywhere looks for ... alien words" (Biegeleisen, cited in: Benedyktowicz 2000, p. 54, translated from Polish). 